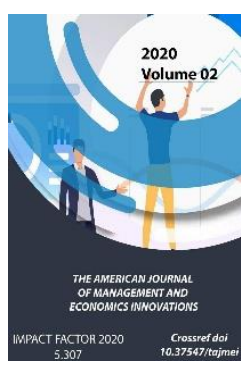

\title{
Development Of The Saving Factor In The Agriculture Of Uzbekistan
}

Bakhtiyor Abdumutalovich Kholmatov

Associate Professor, Fergana State University, Fergana, Uzbekistan

\section{ABSTRACT}

In article worked out the scientific suggestions and practical recommendations directed to effective use of economic resources and improvement of the functioning mechanism of thrifty in the terms of deepening market reforms.

\section{KEYWORDS}

Saving, economic resource, rational, effective use, farm, peasant's farm, mechanism of saving, state program.

\section{INTRODUCTION}

An important factor in increasing the efficiency of economic activity in the current conditions is saving. The solution of such pressing problems as modernization of the material and technical basis of social production, effective employment of labor resources in order to ensure the rapid pace of economic growth, also in many respects, requires adherence to the principles of saving.
President of The Republic Of Uzbekistan Mirziyoyev's address to the Supreme Assembly on the most important priority tasks for 2019 year, the reform of the agricultural sector management system, the introduction of advanced technologies for rational use of land and water resources, ensuring food security was noted as the most important task. Wide application of water-saving irrigation 
technologies; radical revision of the landsupply system for agricultural purposes; further expansion of the activities of multisectoral farms with abundant harvest using land effectively; increasing the number of farmers who have excellently mastered agricultural technologies, are aware of modern methods of production and innovation; solution of tasks such as the introduction of a modern cluster method into the industry has been identified as a solution to problems in the field [1].

Therefore, a new approach to the analysis of production relations in the Republic, from the point of view of the current day to the problems of economical use of resources, referring to changes in the structural changes of the economy, has become a necessity.

\section{MATERIALS AND METHODS}

As a result of our research on the issue of saving, we tried to sort the literature on this topic as follows:

- In studies conducted under the conditions of the planned economic system, more importance is attached to the issues of reducing the level of use of material resources in reducing the cost of products (V.Semyonov, A.Nevelev, V.Sirenko, V.Gab) [2];

- In the last periods of the planned system, organizational aspects of the establishment of the saving order at the state level, the issues of saving labor, the law of saving time, the impact of the cost norm on the saving were studied more (V.Efimov, V.Andrienko, A.Goryunov, V.Stepanov, A.Meshkov) [3];

- Attention has been paid to study the role of the law of saving more time in effective economic conduct in Uzbekistan (N.Usmonov) [4];

- Within the framework of the impact of Science and technology development on the economy, the issues of changing the composition of the gross expenditure on the production of agricultural products have also been studied in the works of Uzbek scientists (X.Nurmuratov) [5].

However, in these theories, without the main emphasis on the limitation of resources, social ownership as an economic basis of saving is shown. At the same time, in these theories and recommendations, there are no substantive proposals and comments on the development of efficiency in the economy of our republic, including agriculture, which provides the union with raw materials and cheap resources.

These studies have been conducted in accordance with the conditions and laws of the former administrative-command system, and new studies have not yet been carried out on the same category of austerity arising from its requirements in the conditions of market relations of the Republic.

\section{RESULT AND DISCUSSION}

We would like to bring some of our analysis on the use of basic resources to assess the level of savings in agriculture in our country.

The main resource - the organization of economical use of water, in many respects, is connected with the effective functioning of water consumer associations.

The organization of water consumer associations in different regions of the country is growing at a different level. One Water Consumers Association in the Republic serves an average of 147 farms, the best indicator in this regard is Surkhandarya (26 units), and the lowest indicator is Khorezm region (263 units). [7]

One association serves every 122 farms in Fergana region. In our opinion, the amount of Water Consumers ' Associations in Fergana and some other regions (for example, the Republic of Karakalpakstan, Kashkadarya, Khorezm, Tashkent) still cannot provide the opportunity to use water efficiently. [6] 
We can conclude from the analysis that among many regions of the Republic Fergana region is not yet in demand, even in agriculture, the cost-effective use of land and Water Resources.

Another important factor is the cost - effective use of the means of production, which is primarily assessed by its compliance with the norms developed on a scientific basis. Its results are expressed through the profit received from the product, which is grown more on account of savings.

But it does not mean that the technical tools available in the enterprises are still fully used. To do this, it is necessary to consider the state of preparation of the equipment for work.

In general, if the coefficient of readiness of each technical tool for operation is calculated on the basis of the formula $\mathrm{Kt}=\mathrm{Mt} / \mathrm{Mj}$, then according to the Fergana region we will have the following indicators: imported hay tractor 0,93 ; ordinary hay tractor - 0,89; chop tractor 0,91 ; transport tractors - 0,82; borons - 0,83; open hay planting site - 0,85 ; combiners - 0,64 ; imported combiners - 0,80; cultivators - 0,91. These coefficients show that the preparation for work on any type of equipment in the region is incomplete. [8] This, in turn, has a negative impact on the level of effective and cost-effective use of these tools.

It is also desirable to consider the compliance of the number of employed labor force with the established scientific standards in the evaluation of the use of labor force resources with savings.

According to scientists, due to the state of the land in different regions of the Republic, the number of people limited to 1 hectare of land varies from 0.29 to 0.49 . And in the non irrigative lands in the middle case is 0,03 people. The number of people limited to 1 hectare of land in Fergana region is set at an average range of 0.38 people, from 0.31 people (Baghdad district) to 0.43 people (Kuva district) in terms of its districts. In particular, the number of people limited to 1 land area in the Yazyavan district is 0.35 people. [8]

In general, over the years being analyzed, the number of employed labor force in the agricultural sector of the region has become more than the established norm. This is explained by the unstable movement of the number of items in the agricultural sector of the region. The fact that the number of agricultural workers in the region has practically not changed in 2015-2019 years still indicates a violation of the principles of saving in the use of the labor force in this area.

\section{CONCLUSION}

As can be seen from the analysis, the Fergana region, as it remains, has not yet entered into full force the factor of saving in the agricultural production of our country. In particular, the full implementation of this factor impedes the impact of complications of the former administrative-command system.

Accordingly, in our opinion, it is necessary to develop austerity measures at different levels of the economy and ensure their performance in the form of a single economy.

The principles of saving should also be expressed in the relations of enterprises with other economic entities - supply and service enterprises, preparatory enterprises and others. For this purpose, it is desirable to promote aspects of thrift in the improvement of contractual relations.

Also, there is no opportunity to create in ourselves the most economical technologies in the cultivation and processing of products. Basically, such technologies are required to be imported from abroad. Accordingly, it is desirable to establish a database on costeffective foreign technologies, bringing it to the attention of economic leaders through various media.

In the formation of thrift as an important and influential factor, it is important to develop and 
establish economic and financial support at the level of the national economy.

One of these is the non - taxation of additional income received as a result of savings in economic activities. The introduction of the practice of determining the additional income generated as a result of the economical use of natural and economic resources and expulsion of the relevant amount of tax from the tax base creates an impressive incentive for savings in economic entities [9].

Also, the level of savings in production depends in many respects on the price policy. Accordingly, the Ministry of finance, the Ministry of Agriculture and water resources on the basis of the state order, the application of the principles that stimulate savings in determining the purchase prices of products produced, will be of great benefit.

In this way, we think that the scientifictheoretical and practical actions taken in the field of saving will give its positive result and effect.

\section{REFERENCES}

1. President of The Republic Of Uzbekistan Mirziyoyev's appeal to the Supreme Assembly about the most important priority tasks for 2019 year. - kun.uz Internet edition. 28.12.2018.

2. Semyonov V.A. Economy of material resources. - M.: Profizdat, 1984. - 158 s.; Economy of resourse saving / A.M.Nevelev, V.A.Sirenko i dr.; - Kiev: Naukova dumka, 1989. - $248 \mathrm{P}$.

3. Economy and thrift - a common cause / A. P. Arkhangelsky, N. I. Dolgushkin et al.; ed. by V. P. Efimov. - M.: Profizdat, 1987. - 208 p.; Andrienko V. F., Vrublevsky V. K., Dolishny M. I. labor Economy. - Kiev: Naukova Dumka, 1984. - 343 p.; Goryunov A. P. Saving time and personal development. - Tomsk: TSU, 1984. - 168 p.; Stepanov V. I., Meshkov A. A. Economy and rationing of material resources. - Moscow: Higher school, 1991 - - 188 p.
4. Usmonov $\mathrm{N}$. The law of saving time and saving farm. - Tashkent: Uzbekistan, 1989. 141 b.;

5. Nurmuratov H. Action of the law of saving time in agriculture of modern scientific and technical progress: Dis.... candidate of economic Sciences. - Tashkent: Tashkent State University, 1982. - 134 p.

6. Information of the General Directorate of Economy of Fergana region for 2015-2019 years.

7. Edgar T.H. Prospects for the development of farms. - T.: New century generation, 2004. - P. 100.

8. Data of the Department of Agriculture and water resources of Fergana region for 20122019 years. 